\title{
Penalty Clauses: A Comparative Analysis between the Turkish and Ethiopian Laws
}

\author{
Kamil Abdu Oumer \\ Law at Wollo University, Dessie, Ethiopia \\ Email: kamillaw2009@gmail.com
}

How to cite this paper: Kamil A. (2017) Penalty Clauses: A Comparative Analysis between the Turkish and Ethiopian Laws. Beijing Law Review, 8, 423-439. https://doi.org/10.4236/blr.2017.84023

Received: August 27, 2017

Accepted: November 26, 2017

Published: November 29, 2017

Copyright (C) 2017 by author and Scientific Research Publishing Inc. This work is licensed under the Creative Commons Attribution International License (CC BY 4.0).

http://creativecommons.org/licenses/by/4.0/

\begin{abstract}
Both the Ethiopian Civil Code and the Turkish Code of Obligation recognized party autonomy to agree a penalty clause either as an ex-ante estimation of a possible damage from non-performance of an obligation or as a sanction for default. But, despite the fact that both countries adhered to the continental legal system, there are considerable differences between the two regarding the regulation of penalty clauses. The paper examines the regulation of penalty clauses in legal literature as well as the laws of the two countries. It, in particular, analyses the two laws on the type of principal obligations that can be secured by penalty clauses, the possibility of claiming the enforcement of both the contract and the penalty, the relation between fault of the debtor \& damaged suffered by the creditor on one hand and the enforcement of the agreed penalty on the other hand as well as possible court intervention in altering the free wills of the parties. A comparative approach is used throughout the paper in which the differences and similarities of the two systems are examined.
\end{abstract}

\section{Keywords}

Damages, Ethiopian Law, Obligation, Penalty Clause, Turkish Law

\section{Introduction}

Parties in a debt relation may secure the performance of their debt through penalty clauses as they may secure through movable or immovable properties or personal guarantors (Cansel \& Özel, 2007). Penalty clauses are contractual agreements between a creditor and a debtor in a certain debt relation in which they determine the effects of non-performance of the obligation. They usually have three purposes. They may serve as a good faith estimation of the future loss due to a possible non-performance, means to coerce performance or as a limitation of the liability of the debtor (Graves, 2012). They may also be claimed 
together with the performance of the principal debt or as an alternative to damages due from non-performance.

Penalty clauses are regulated under the Turkish Code of Obligation 6098/2011 and the Ethiopia Civil Code Proclamation Number 165/1960. Despite the fact that both countries adhered to the Civil Law legal System, there are considerable differences on the provisions governing penalty clauses and, despite the time gap between the date of promulgation of the two laws, there are considerable similarities too. ${ }^{1}$ This paper is a comparative study of the laws of Turkey and Ethiopia on the regulation of penalty clauses. A comparative study of Ethiopian laws with laws of developing nations in general and non-Western legal systems in particular is very rare. The author chooses the two legal systems due to his exposure for both systems and with the believe that a comparative study between laws of countries that are at a relatively nearer economic condition may generate better lessons. Further, while the Ethiopian law of obligation is governed under a half century old Civil Code, the Turkish Code of Obligations is among the very recent Codes.

The first part of the article explains the concept of penalty clauses both in legal literature and the Turkish \& Ethiopian laws. The second part discusses different types of penalty clauses while the third part is about the relation between penalties, faults of the debtor and damages caused to the creditor. The fourth part is about the relationship between penalty clause \& the principal obligation and in the fifth part, the power of courts to (in/de)crease penalties is examined. Finally, there is a short summary of the paper.

\section{Definition and Objectives of Penalty Clauses}

Various domestic laws and international as well as regional agreements define penalty clauses in different ways. The Council of Europe Resolution regarding Penalty Clauses in Civil Laws, for example, defines penalty clauses as "any clause in a contract which provides that if the promisor fails to perform the principal obligation, he shall be bound to pay a sum of money by way of penalty or compensation." From the definition, the purpose of the clause may be either to penalize the defaulting debtor or to compensate the creditor. The stipulation may also be either a fixed amount or a procedure how to determine the damage ex-post (Scottish Law Commission, 1999).

Punitive damages are allowed both in common law and civil law legal system for torts. But, there are divergent views in relation to penalty clauses in contractual obligations (Calleros, 2006). In the common law legal system, penalty clauses are in principle un-enforceable while they are generally enforceable in the civil law legal systems (García, 2012). In the continent, penalty clauses are agreements that may be made to force a debtor to perform (i.e. as penalty against the de${ }^{1}$ While the Ethiopian Civil Code that incorporates provisions of Contract Law, enters in to force in 1960, the Turkish Code of Obligation is promulgated in 2011. The comparison between the two laws, therefore, may be taken as a comparison between the legal philosophy during the two distinct periods (i.e. the beginning of the second half of the $20^{\text {th }}$ century and the $21^{\text {st }}$ century). 
faulting party) or as a compensation up on non-performance. In the common law, on the other hand, only liquidity damages may be agreed by the parties in advance but not a punitive damage.

The common law rejects punitive damages in contractual obligations in its totality. Any agreement between parties whose main objective is to punish either party is unacceptable (Gassim, 2004). At the beginning, penalty clauses were totally rejected based on the principle of equity and prohibition of usury (Scottish Law Commission, 1999). Through time, however, it became clear that some losses are difficult to ascertain by courts. Therefore, an ex-ante agreement to pay a certain sum up on non-performance of a certain obligation was recognized (Gassim, 2004). This is called liquidated damage in common law legal systems, not penalty. Liquidated damage clauses protect the creditor from the burden of proving fault and loss in case of non-performance with no threatening purpose (Erdem, 2009). There is a long standing believe in the common law that an injured party should not be entitled more than what s/he would have gained had the contract be performed (Sol'orzano, 2009). Penalty clauses which are agreed "in terrorem" to coerce the debtor perform are un-enforceable (Study Group on a European Civil Code \& Research Group on EC Private Law, 2009). But, the line between liquidated damage and penalty clause is blurred that courts may enforce some penalty clauses as liquidated damages and may reject some liquidated damage clauses as penalties (Scottish Law Commission, 1999).

In the United States, liquidated damages are enforceable if and only if the following three conditions are fulfilled. The parties should intend to liquidate potential damages due to the non-performance of the obligation in advance. If they intend to secure performance, it is penalty and, if they intend, to estimate damages, it is liquidated damage (Benjamin, 1960). The agreed sum should also be a reasonable estimation of the expected loss. It may not be reasonable in relation to the actual lose. But, so long as it is reasonable in line with the ex-antee stimation, common law courts may enforce it (De Geest \& Wuyts, 1999). The liquidated damage is enforceable if it is reasonable estimation of the possible future loss from the non-performance of the obligation even if no actual loss occurred (De Geest \& Wuyts , 1999). While examining the reasonability of the agreed sum, common law courts consider benefits that would have been obtained had the obligation been enforced and the bad faith of either parties (De Geest \& Wuyts , 1999). Finally, it should be impossible or difficult to assess actual losses caused by the non-performance of the obligation (Sol'orzano, 2009). US courts, however, enforce penalty clauses in exceptional known cases. In most states in the United States, punitive damages are enforceable in relation to promises to marry and break of obligation by public service companies that also have duty of care (Calleros, 2006). Punitive damages may also be enforced if the conduct leading to the non-performance of the contract is also a tort (US Restatement (Second) Of Contract).

In the continental system, enforcement of penalty clauses went back to the 
Roman law. The Roman law used to allow literal enforcement of penalty clauses so long as it is agreed by parties (García, 2012). There are two main objectives of penalty clauses in the continental law system; to secure performance of the debt and to estimate damages indicating that it has both sanction as well as compensation elements (Benjamin, 1960). But, almost all continental law systems allow the reduction of excessive penalties (García, 2012).

Penalty clauses have a number of advantages for both the parties and courts. They relieve the court from calculation of damages ex-post while it creates certainty in, specially, contractual transactions. In addition, it help include non-calculable and non-material damages (De Geest \& Wuyts, 1999). Further, it deters recklessness or intentional torts and help reduce self-help measures (Calleros, 2006). It also provides an incentive not to incur much reliance cost for the creditor and take appropriate care in order to perform for the debtor (De Geest \& Wuyts, 1999). On the contrary, there are arguments that penalty clauses increase transaction costs, affects entry in to contract, and hinders efficiency breach of contracts (De Geest \& Wuyts, 1999). But, the effect of penalty clauses on efficient breach is argumentative (Nordin, 2014).

Coming to the Turkish law, under the Turkish law of obligation, Parties may agree any sum as penalty clause and there is no distinction between penalty clauses and liquidated damages. The law recognizes three main functions of penalty clauses; forcing performance, estimating damage and simplifying unilateral cancellation (Tiryaki, 2005). Penalty clauses are due when the principal debt is not performed at all or is not performed appropriately or on the agreed time and place (Cansel \& Özel, 2007). The principle in the Ethiopian Civil Code is also similar. The Ethiopian Civil Code permits parties to extend or limit or fix their liability in case of non-performance. Parties may extend their liability and agree that they may be liable even if non-performance is prohibited by force majeure (See article 1886 of Civil Code of the Empire of Ethiopia (here after CCE)). They may also limit their liability "under the contract and provide that they will not be liable unless they commit a fault" (CCE, article 1887). Finally, they may agree a penalty clause for nonperformance of an obligation.

In the Ethiopian context, Parties may agree a penalty clause as they wish and there is no distinction between penalty clauses and liquidated damages.

Article 1889. - Penalty.

The parties may fix the amount of damages which will be due, should a party fail to discharge his obligations or to discharge them completely and in due time.

Under the Turkish law of obligation, the stipulated penalty can be any economic value (Tamer, 2013). In the Ex-Turkish Cod of Obligation, the term "Tediye" used to indicate that the value could be only monetary value (Kilıçoğlu, 2015). Under the New Code, however, it is not required to be a monetary sum. It even may be refraining from doing a certain act or benefiting from a certain thing. But, things that have only moral values may not be agreed as a penalty value for they may not be executed through specific performance (Eren, 1999). 
Likewise, the agreed penalty may be either monetary or any other value under the Ethiopian law. The Ethiopian Civil Code clearly provides that parties may agree for the application of sanctions other than paying certain sums against the debtor (CCE, article 1895). But, it is also clear that the agreed sanctions should be defined, possible, legal and may not compromise the personal liberty of the individual.

In the Turkish law of obligation, penalty clauses are dependent obligations whose existence depends on the principal obligation. Even if penalty clauses are always contractual obligations in nature, the principal obligation need not be a contractual obligation (Oğuzman, 2009). It may be a contractual (including gratuitous contracts), extra-contractual, and/or legal obligation (Eren, 1999). Under the Ethiopian law too, the provisions governing penalty clauses are under the chapter "special terms of obligations or contract." In addition, the provisions regulating contracts "shall apply to obligations notwithstanding that they do not arise out of a contract" (CCE, article 1667). Therefore, the principal obligation need not necessary be a contractual obligation. But, there is no clarity in the Ethiopian law whether penalty clauses may be agreed to secure legal obligations or not. Still, it is possible to argue for based on the general principle of contractual autonomy.

There are some obligations that may not be secured by penalty clauses. Penalty clauses are not allowed to secure obligations that are related with the privacy of the individual like penalty clauses in relation with promises to marry are invalid under the Turkish law (Cansel \& Özel, 2007). In Ethiopia law, there are two conflicting rulings in relation with betrothal (promise to marry) contracts. Under the Civil Code, it is possible to secure contracts of betrothal with penalty clauses (CCE, article 574). ${ }^{2}$ But, regional Family Codes that came in to effect following the Federal system prohibited it. ${ }^{3}$

Penalty clauses against weaker parties in some contractual relations are not also enforceable (Cansel \& Özel, 2007). Under the Turkish law, it is not legally possible to provide a penalty clause that is against only the worker in contract of service, in contract of rent, for not paying the rent fee on time and, in contract of agency, for unilaterally cancellation of the agency contract (Cansel \& Özel, 2007; see also Turkish Code of Obligation (herein after TBK) articles 346, 420, 512). Under the Ethiopian Civil Code too, penalties agreed to be paid by the employee to the employer are not enforceable (CCE, article 2591). ${ }^{4}$

The Supreme Court of Turkey has ruled that penalty clauses are not allowed for monetary obligations/obligation to pay (Cansel \& Özel, 2007). The reason behind the position of the Supreme Court is that there is already a legal interest ${ }^{2}$ The Civil Code provisions in relation to family law are still applicable with in regions that have not got their family code yet.

${ }^{3}$ See for example article 9 of the Amhara Regional State Family Code.

${ }^{4}$ Ethiopia has legislated a separate Labor Code. But, the new Code dose not repeal the Civil Code provisions on employment relations in their totality. It rather prefer to repeal any law which has a contrary rule to issues covered by the Code. Since penalty clauses are not included in the new Code, the provision of the Civil Code shall be valid. 
due for non-performance. Despite the ruling of the Court, however, there are still arguments for the possibility of penalty clauses so long as the legal interest is abolished (Oğuzman \& Turgut, 2009). In Ethiopia, there are two different rulings concerning penalty clauses in relation to obligation to pay. The first one is the provision of the Civil Code under the general contract provision that allows parties to fix a higher interest rate than the legal rate.

Art. 1803. - Money debts. - 1. Interest for default.

1) Where the debtor owes a money debt and he is in default, he shall pay interest for default at the rate fixed by law (Art. 1751) notwithstanding that the contract fixes a lower rate in respect of interest to be paid before the debt is due.

2) Where a higher rate of interest is fixed in the contract, such interest shall be due in lieu of interest under sub-article (1).

3) Interest shall be due notwithstanding that no loss is incurred by the creditor.

Parties may fix a rate of interest higher than the legal rate, but not a lower rate and interests are due even if no loss is occurred to the creditor (CCE, article 1803). In addition, if the actual damage caused to the creditor exceeds the interest rate, "such damage shall be fully made good by the debtor where he knew of the circumstances on entering into the contract or where non-performance is due to the debtor's intention to cause damage or to his gross negligence or grave fault' (CCE, article 1805). The agreement for higher interest can be considered as a penalty clause. Therefore, we can conclude that parties may agree a penalty clause in the form of a higher interest rate for non-performance of monetary obligations.

The other ruling is the provision of the Civil Code regarding damages in relation to delay to return borrowed money or a fungible thing. The borrower shall pay legal interest when she/he is late in returning the thing lent or paying at the due date (CCE, article 2489(1)). The Code further provides that "any provision increasing the liability of the borrower shall be of no effect" (CCE, article 2489(2)). This has also been affirmed by the Cassation Division of the Ethiopian Federal Supreme Court which ruled that, in loan contracts, parties may not agree higher interest, any penalty clause for that matter, more than the legal interest rate (Supreme Court of Ethiopia Cassation Division file No. 59882/2003). Since the special provision prevails over the general in legal interpretation, we can conclude that a penalty clause may not be provided in a contract for money loan. But, it does not mean that penalty clauses are not allowed in all monetary obligations. For monetary obligations other than loan contracts, parties may provide a penalty clause in the form of interest rates that are higher than the legal rate.

\section{Types of Penalty Clauses}

Penalty clauses are dependent obligations that are accessary to a principal debt. If the principal debt is performed according to the conditions, the penalty clause may not be an issue. When the principal obligation is not performed at all or not 
performed as it should have been performed, the creditor may claim both the performance of the contract and the penalty, either of the two or the debtor may relief itself from performance by paying the penalty in accordance with the agreement.

\subsection{Alternative Penalty Clauses}

Alternative penalty clauses are penalty clauses that empower the creditor to choose either the performance of the contract or the penalty, but not both. In most European countries, stipulated damages replaces legal damages so that parties may only ask for the agreed sum or the performance of the contract (Study Group on a European Civil Code \& Research Group on EC Private Law, 2009). Under the Turkish law, unless there is an agreement to the contrary, a penalty clause is considered to be an alternative penalty clause (Şener, 1992).

Article 179 (I)

If a penalty is agreed for total non-performance or defective performance, unless otherwise agreed in the contract, the creditor may claim either the performance of the contract or the penalty.

Once the creditor makes his choice clear, he may not turn back. If he chooses the performance of the contract, he may claim damage if the debtor still failed to perform, but not the penalty and vice versa (Oguuzman \& Turgut, 2014). The parties may also agree that the creditor should firs ask for performance and then for the penalty (Tiryaki, 2005).

In Ethiopia, the principle is that a penalty clause is an alternative penalty clause. The creditor may claim either the performance of the obligation or the penalty. Article 1889(1) of the Civil Code provided that "unless otherwise agreed, the creditor may require the performance of a contract which includes a penalty." Therefore, the parties may agree that the creditor may claim only the penalty, not the performance of the contract. The wording of the sub-article does not, however, show the possibility of agreement to claim both the penalty and the performance of the contract in case of non-performance.

\subsection{Cumulative Penalty Clauses}

Cumulative penalty clauses enable the creditor to claim both the performance of the obligation and the penalty in case of non-performance. In the ancient Roman law, the creditor was entitled to claim both the performance and penalty in all circumstances (Benjamin, 1960). Latter, cumulative clauses were restricted to exceptional circumstances. The Resolution of Council of Europe in Relation to Penalty Clauses expressly prohibited the possibility of requiring both the penalty and the performance of the obligation except for delay of performance (Council of Europe Regulation (78)3, article 2). The UN Convention on Penalty Clauses, on the contrary, permits the possibility of claiming both the penalty and the performance of the contract even for cases outside delay (UN Uniform rules on contract clauses for an agreed sum due up on failure of performance, article 6). 
Under the Turkish law, the creditor may require both the performance and the penalty if penalty is agreed for the delay or performance in a place other than the agreed place (TBK, article 179). The law simply stipulates that the creditor may ask both the penalty and the performance if the penalty is agreed for non-performance at the agreed time and place without any clue whether the parties may agree on the possibility of claiming both the performance and penalty for breaches other than the time and place of performance. From the first paragraph of article 179, it is clear that the parties may agree to the effect of claiming both the penalty and the performance of the contract. But, whether paragraph 2 is limiting the possibility for only breaches in relation to place and time of performance is argumentative. Neither paragraph 1 nor paragraph 2 are prescriptive or prohibitive by their nature. Due to this reason, there are conflicting arguments in the Turkish legal doctrine (Oğuzman \& Turgut, 2014). But, paragraph 2 has made it clear that the creditor may not claim if it accepts the performance without any reservation or expressly denounces its right to claim both the penalty and the performance. The Turkish Supreme Court also ruled that, if a creditor accepted a late performance, he may not claim the agreed penalty unless he accepted the performance with written opposition/reservation or the contract itself provides that the creditor may claim the penalty even if he accepts late performance without written reservation (Turkish Supreme Court Decision, E 2012/5327, K. 2012/7205 T. 06.12..2012). Cumulative penalty clauses may not be transferred to third party when the debt is transferred (Cansel \& Özel, 2007).

In Ethiopia, claiming both the performance of the obligation and the penalty is possible only if the penalty is agreed "in respect of delay or the non-performance of a collateral obligation" (CCE, article 1890(2)). Unlike the Turkish law, the Ethiopian law is clear that parties may not agree for the claim of both the penalty and the performance for other breaches than delay or breach of collateral obligations. Still, it is not clear whether the creditor may require both the performance of the collateral obligation and the penalty as well as the principal obligation. The essence of the law seems that the creditor may not claim both the performance of the collateral obligation and the penalty. But, he/she may claim both the penalty and the performance of the principal obligation.

\subsection{Exclusive Penalty Clauses}

This type of penalty clause hardly has the characteristics of a penalty clause. Whereas penalty clauses, in principle, are either compensations fixed in advance or sanctions for non-performance of an obligation, exclusive penalty clauses are privileges granted for the debtor. In the Turkish Code of obligation, the debtor is entitled to relief himself from performing the obligation by paying the agreed sum. Therefore, the creditor has no right to claim damages (Eren, 1999). In order to relief himself by paying the agreed sum, the debtor is expected to prove that the agreed sum is not a penalty, but an agreement to relief him from the obligation to perform by paying the stipulated sum (Oğuzman \& Turgut, 2014). 
Unlike the Turkish law, exclusive penalty clause is not regulated under the Ethiopian contract law. But, based on the general principle of contractual freedom, there is no legal rule that prohibit if parties agree exclusive penalty clause.

\section{The Relation between Fault, Damages and Penalty Clauses}

The relation between the fault of the debtor, the damage caused to the creditor and enforceability of penalty clauses is among the basic issues in the discussion of penalty clauses. The principle is that penalty is enforceable in spite of the fact that the debtor has not committed any fault and the creditor did not sustain damages. However, various domestic laws and international agreements have different regulations.

The general principle in the continental legal system is that there is no requirement to sustain loss in order to claim the performance of a penalty clause. Under the German law, for example, sustaining actual loss is not a condition to claim the stipulated sum (Pieck, 1996). The principles of European Contract Law also assert that there is no need to proof damages on the part of the creditor (The Principles of European Contract Law (2002), article 9: p. 509).

The relation between the fault of the debtor and the enforcement of the penalty clause is argumentative. While, under the UNIDROIT principles, penalty may not be paid if non-performance is due to force majeure (UNIDRIOT, 2010), under the Resolution of Council of Europe in Relation to Penalty Clauses, the penalty may be claimed only if the debtor is liable for the non-performance of the principal obligation (Council of Europe regulation(78)3, article 4). Likewise, the UN Convention on Penalty clauses also exclude the possibility of claiming penalty from a debtor who is not liable for the non-performance of the contract (UN Uniform rules on contract clauses for an agreed sum due up on failure of performance (annex 1), article 5).

In the Turkish law of obligation, the creditor may claim the penalty notwithstanding the fact that $\mathrm{s} / \mathrm{h}$ sustains no loss. Nor is the fault of the debtor required to claim the agreed penalty. However, proving the faults of the debtor is necessary when the creditor want to claim damages over the agreed some (TBK, article 180). The debtor may also relief himself by proving that he is not responsible for the non-performance of the contract (Oğuzman \& Turgut, 2014).

Under the Ethiopian law, penalty may be claimed when the creditor is entitled to claim damages.

Article. 1891. - Conditions of application.

The penalty shall be due whenever the creditor is entitled to claim damages by reason of non-performance of the contract.

Therefore, the debtor may raise force majeure as a defense (Mulugeta, 2010). The Cassation Court of the country also affirmed that force majeure can be a defense (Supreme Court of Ethiopia Cassation Division file no. 58258/2003). In addition, the creditor should put the debtor in default notice if it is legally necessary (CCE, article 1772-1775). As there is no duty to prove the fault of the 
debtor in claiming damages, the debtor may not, however, raise absence of fault as a defense unless the obligation is an obligation of diligence or the law provides so (CCE, article1171(1) \& 1795). But, the fault of the creditor may be raised as a defense. In addition, in a contract made for the exclusive advantage of one of the parties, the other party may not claim damages unless non-performance is due to gross fault (CCE, article 1796). Therefore, penalty clauses agreed for the performance of gratuitous obligations may be claimed only if the debtor commits a grave fault.

From the discussion, proving the fault of the debtor is not, in principle, a requirement for enforcing penalty clauses in both the Turkish and Ethiopian laws. Exceptionally, under Ethiopian law, however, proving the fault of the debtor is a pre-condition to claim the enforcement of a penalty clause agreed with gratuitous obligations. But, it is against the very purpose of providing penalty clauses. Therefore, it is recommended that the fault of the debtor should not be a precondition to require the enforcement of penalty clauses even if they are agreed for performance of gratuitous obligations.

In Ethiopia, the occurrence of actual loss is not also necessary to claim the penalty.

Article. 1892. - Actual damage.

1) The penalty shall be due notwithstanding that no actual damage was caused to the creditor.

The creditor has no obligation to prove damage except in case of claiming damage over the agreed penalty. In case the loss of the creditor exceeds the agreed penalty, the creditor has to proof damages and the negligent or intentional fault of the creditor (CCE, article 1892).

\section{The Relation between Penalty Clause and the Principal Debt}

Penalty clauses may not stand alone. They are dependent obligations which are accessary for the principal obligation. If there is no line that links the (non) performance of the principal debt and the penalty clause, it is an alternative obligation, not a penalty clause (Cansel \& Özel, 2007). Penalty clauses may be provided at the time of the conclusion of the principal obligation/contract or subsequently (Tamer, 2013). If the principal debt is invalid or void or may not be validly claimed, the penalty may not be an issue (TBK, article 182). But, if the principal obligation becomes impossible after the due date, the penalty shall remain valid (Cansel \& Özel, 2007). A penalty clause should also be made in the form the principal debt is made (Turkish Supreme Court, E 2005/6737, K. 2006/6400, T. 09.11.2006). Further, if the principal debt is transferred to another person, so does the penalty.

Under the Ethiopian law of contract too, the invalidation of the principal obligation makes the penalty clause void. The Code specifically prescribes that "a penalty shall be of no effect where the contract in which it is prescribed is inva- 
lidated" (CCE, article 1894). Therefore, we can conclude that the penalty clause shall remain valid so long as the principal obligation is not actually invalidated even if it is defective. A defective contract is actually valid until it is invalidated. But, the invalidity of the penalty clause has no effect on the principal obligation.

\section{Court Intervention to (In/De)crease an Agreed Penalty}

Court intervention in penalty clauses/liquidity damages has been one of the main differences between the Common Law and the Civil Law legal systems. In the Common Law legal system, the court either reject a stipulated sum as a penalty or enforce it as a liquidity damages (Nordin, 2014). The stipulated sum may be less than the expected damage that is reasonably estimated ex-ante but not in excess of the estimated expectation damages (Schwartz \& Edlin, 2003). If the stipulated sum is found less than the actual loss before common law courts, it shall be taken as contractual limitation of liability (Vitkus, 2013). But, there are recent trends in enforcing penalty clauses by reducing the stipulated some to the level of the actual loss (Vitkus, 2013).

In the Continent, courts are usually allowed to intervene. French Courts, for example, may intervene in penalty clauses when the debtor had performed in part or the penalty agreed is grossly excessive (Calleros, 2006). The Draft European Private Law Principles also follow the French approach and proposes for freedom of parties in fixing the agreed sum and the power of the court to reduce it in case it is grossly excessive (Study Group on a European Civil Code \& Research Group on EC Private Law, 2009). The Court may exercise this power even if the agreed sum seems reasonable ex-ante if the ex-post assessment of damages shows that the agreed sum is grossly excessive (Vitkus, 2013). But, the court should not go far beyond preventing abusive behaviors and reduce the agreed sum below or to the level of the actual loss (Study Group on a European Civil Code \& Research Group on EC Private Law, 2009). Under UNIDROIT principles, parties may agree that the penalty may not be reduced even if the debtor partially performed but, the court may reduce excessive stipulations even if parties agreed to the contrary (UNIDRIOT, 2010). Under the Principles of European Contract Law, the court may reduce penalties whenever it founds that it is excessive in relation to "the actual loss or other circumstances" (Principles of European Contract Law, article 9).

In Turkish law, reducing an excessive penalty by the court has been recognized both in the ex and current Codes of Obligation.

Article 182 (II)

The Judge shall spontaneously reduce a penalty it believes to be excessive.

Courts are empowered to reduce excessive penalties, be it in alternative or cumulative penalty clauses (Çinar, 2009). There are, however, some pre-conditions for reducing penalty clauses. Both the principal debt and the penalty should be valid, the penalty should be due, the penalty should not be already paid and the penalty should be excessive (Eren , 1999). 
What is a grossly excessive sum attracts divergent views in Turkish doctrine. Some commentators argue that the sum should be too high to the extent of pushing the debtor to bankruptcy or ruin its economic life. Accordingly, the court should not consider to reduce the penalty simply for it may create some difficulty to the debtor or may cause loss (Tamer, 2013). Others, on the other hand, are of the opinion that the issue has been left to the discretion of the court (Çinar, 2009). But, the court may not change the object of the obligation agreed in the penalty clause (Tamer, 2013). It may not also avoid the penalty in its totality in the name of reduction (Eren, 1999). Further, the penalty should not be lowered to the level of actual loss and should always remain above the actual loss (Reisoğlu, 2006). In addition, the court should act reasonably while exercising its discretion to reduce the penalty as prescribed under article 4 of the Civil Code (Tamer, 2013).

In determining the excessiveness of the agreed sum, courts consider, among others, the actual loss, the un reasonable loss incurred due to the acts of the creditor, the economic condition of the parties and the existence of insurance (Cansel \& Özel, 2007). In addition, the deviation of the debtor from the contract, the level of fault of the debtor, the type and duration of the contract and the possible contributions of the creditor for the loss should be considered (Eren, 1999). Therefore, the reduction takes in to account the personal conditions of the parties. But, there is no indication in the Code as to the time reference while examining the sum to be excessive or not. No clue whether it should be considered ex-ante or ex-post. Some writers contends that the court should consider the value of the agreed some at the time of the hearing to determine whether it is too high or not (Tamer, 2013).

There are, circumstances that a court may not reduce the stipulated amount even if it is grossly excessive. Under the German law, for example, if the sum had already been paid or is agreed by a merchant in his commercial transaction, courts may not reduce the penalty even if it is grossly excessive (Pieck, 1996). Under the Turkish law too, a merchant may not be entitled for reduction of penalty for commercial transactions because of the fact that merchants are expected to observe duty of care to the extent of a prudent business man in their business dealing (Turkish Commercial Code, herein after TCC, articles 12, 13, $14,14 \& 22)$. But, under article 2 of the Turkish Civil Code, every right/duty is subject to the principle of good faith. Therefore, there are arguments that penalty clauses against a merchant may be reduced if they are agreed contrary to good faith (Tamer, 2013). In addition, Turkish courts are also considering reduction of a penalty in relation to merchants in case the penalty is considered to be against good faith and there has been business relation between the parties ( $\mathrm{Ta}$ mer, 2013).

In many civil law countries, penalty clauses are rejected for policy reasons like for being immoral, contrary to good faith and/or unlawful enrichment (UN Secretary General Report). In the Turkish legal literature, there are two opposing views about the morality of a grossly excessive penalty. Some commentators 
claim that a grossly excessive penalty may be considered void for it is immoral (Çinar, 2009). Others rejected the claim as it is beyond the realm of morality (Eren, 1999).

Coming to the Ethiopian law, parties may freely determine the amount of the penalty. ${ }^{5}$ Courts also has little power either to increase or decrease the penalty agreed by the parties free will.

Article. 1893. - Variation of penalty.

The agreed amount of the penalty due for non-performance may not be reduced by the court unless partial performance has taken place.

The mandatory provision prohibits the court from reducing the penalty unless there is part performance on behalf of the debtor. Therefore, there is no distinction among various obligations in which the court may intervene in some cases and may not in the other. The court is deprived of the power to reduce a penalty agreed by the parties no matter who the parties are and no matter what the obligation is. The only exception left is the existence of partial performance.

Penalty clauses are contractual obligations between the parties despite the fact that they are dependent obligations. Therefore, the rules of general contract shall apply. Under the rules of the general contract, "the court may not vary a contract or alter its terms on the ground of equity except in such cases as are expressly provided by law" (CCE, article 1763). Accordingly, a contract may be varied if the law provides. In the rules of general contract, a court may vary a contract if there is a special relation between the parties that "compels them to act with equity", in contracts made with public administration, "where the circumstances in which it was made have changed through an official decision in consequence of which the obligations assumed by the party who contracted with the administration have become more onerous or impossible", "where the performance by the other party of his obligations has become partially impossible and there is no ground for cancelling the contract" (CCE, article 1763-1770).

Whereas the provisions dealing with penalty clauses prohibited reduction of the penalty except when the obligation is partly performed, the general contract law rules permit variation in the above circumstances too. There can be two different possible arguments on the applicability of legal rules governing variation of contract to vary penalties. The first argument may be that, since penalty clauses are terms of a contract, the provisions in relation to variation of contracts may also consider the reduction or increment of the contract. The other possible argument is that, since the provisions regulating penalty clauses are

\footnotetext{
${ }^{5}$ An exception to this rule is provided under article 594 of the Commercial Code. The article provides that "The carrier mar by agreement limit his liability for any total or partial loss of or damage to goods or registered baggage. Any such limitation shall be of no effect where the agreed compensation is so disproportionate to the value of the object carried as to make the carrier's liability negligible." Another exception is the prevision of the Civil Code regarding betrothal. Article 574 of the Code dictates that if a penalty attached with a betrothal, the agreed penalty "may be reduced having regard to the circumstances of the case... It may be reduced where it appears that it is manifestly exaggerated." Note that the family law provision of the Civil Code, however, is applicable in regions that has not legislated their own family code.
} 
found under the section "special terms of obligation or contract" and the rules on variation of contracts are general provisions, penalties should not be decreased/increased except if there is part performance. Since the law expressly prohibited reduction of penalty clauses except in case there is part performance under a title "variation of penalty"; penalty clauses are special contractual commitments and should not be subjected to the provision of the general contract while there is special provision concerning the issue. The legislator most likely has permitted reduction of penalties only in case of part performance.

Another possible ground that may be taken as a ground for the reduction of the penalty clause is unconscionablity. But, unconscionable contracts are not invalid for mere reason of favoring one party. There should be other factors that potentially vitiates the consent of the other party like immediate wants of the party, simplicity of mind, senility or manifest business inexperience (CCE, article 1710). In addition, the court has no power to reduce the obligation. It may rather invalidate it. Only the party in whose favor the contract is may correct the imbalance and escape the invalidation of the contract (CCE, article 1812). Therefore, even if penalty clauses are contractual obligations and the penalty clause may be invalidated by the court for unconscionability or corrected by the parties, it may not be a ground to reduce excessive penalties under the Ethiopian law of obligation.

From the above discussion, unlike the Turkish law and the developments in the other Civil Law countries, Ethiopian courts may reduce a penalty clause if and only if the debtor had performed in part. But, for one thing, with its bid to join the World Trade Organization and the increasing participation in international trade, it is advisable to harmonize its legal rules with the rest of the world in order to promote certainty in contractual transaction. For the other, the law need to protect citizens from non-reasonable penalties. It may be argued that the court may invalidate the penalty based on unconscionability. But, it is preferable if the court have the power to reduce the penalty and keep the contract enforceable. Therefore, it is recommended if courts are allowed to reduce unreasonably excessive penalties.

The power of the court in reducing penalty clauses is also argumentative. Under the German law, courts may reduce the penalty only up on the request of the debtor (Çinar, 2009). In the Turkish law, on the other hand, the court should not wait the application of the debtor to reduce the excessive penalty. A judge is under an obligation to reduce an excessive penalty (TBK, article 1821(II)). In Ethiopia, the matter is blurred. The drafters of the Code focus on the impossibility of reduction of the penalty clause rather than on the possible and/or mandatory reduction of penalty clause as the provision stipulates that the penalty may not be "reduced by the court unless partial performance has taken place." This automatically indicates that it is possible for the court to reduce the penalty if the debtor has performed in part. But, it is not clear if the court is under obligation and whether it may decide by itself without waiting the application of the debtor. 
Finally, civil law courts have no power to increase a penalty stipulated by parties in principle. But, in exceptional circumstances, they may increase it. Turkish Courts have no power to increase an agreed penalty except in case the actual loss caused to the creditor is greater than the stipulated penalty and the creditor can prove the fault of the debtor (TBK, article 180(II)). Therefore, a court may respond to the claim of a creditor who proofs the fault of a debtor which caused damages in excess of an agreed penalty. In Ethiopia, as discussed above, courts may grant the creditor a damage over the penalty when a greater damage is caused against him due to the fault of the debtor.

\section{Conclusion}

Both Ethiopia and Turkey belong to the continental legal system. They both recognized penalty clause, be they as a means of sanctions or pre-estimations of possible damage from the non-performance of the obligation. Penalty clauses may be agreed to secure any obligation so long as the obligation is neither illegal nor immoral except obligations that may inhibit the personal freedoms of the parties like promises to marry, obligations in which one of the party is weaker and worth of legal protection like employment contracts and house rent. Whereas under the Turkish law, penalty clauses for monetary obligations are not enforceable, in Ethiopia, parties may fix an interest rate higher than the legal rate in the form of penalty for monetary obligations except in contracts for loan of money.

In both the Turkish and the Ethiopian laws, the principle is that penalty clauses are alternative penalty clauses unless parties agree otherwise. In Ethiopia, parties may agree to claim both the performance of the contract and the penalty clause only in case the penalty is made for delay and for non-performance of accessary obligation. Under the Turkish law, however, the law simply stipulates that the creditor may claim both the penalty and the performance if the penalty is agreed for breaches of the time and place of performance leaving a space for arguments regarding whether the parties may agree on the possibility of claiming both the performance and penalty for breaches other than the time and place of performance. In both the Turkish and the Ethiopian law, parties may agree exclusive penalty clauses.

Finally, Turkish courts have the power to reduce a penalty if the judge found it to be excessive in relation with the actual loss. In Ethiopia, courts may reduce the penalty only if the obligation is partly performed.

\section{References}

Benjamin, P. (1960). Penalties, Liquidated Damages and Penal Clauses in Commercial Contracts: A Comparative Study of English and Continental Law. The International and Comparative Law Quarterly, 9, 600-627. https://doi.org/10.1093/iclqaj/9.4.600

Calleros, C. (2006). Punitive Damages, Liquidated Damages, and Clauses Pénales in Contract Actions: A Comparative Analysis of the American Common Law and the French Civil Code. Brook. J. INT'L L, 32, 69-119. 
Cansel, E., \& Özel, Ç. (2007). Penalty Clauses under the Turkish Law of Obligation. (In Turkish)

http://journal.yasar.edu.tr/wp-content/uploads/2014/01/19-E.CANSEL-\%C3\%87.-\%C3 \%96ZEL

Çinar Ö. (2009). Reduction of Penalty Clauses under the Turkish Code of Obligation and the German Civil Code (Turkish). Istanbul Ticaret University Journal of Social Science, 8, 91-115.

Civil Code of the Empire of Ethiopia (CCE), Proclamation No. 165/1960.

Commercial Code of the Empire of Ethiopia, Proclamation No. 166/1960.

Council of Europe Resolution (78) 3 Relating to Penal Clauses in Civil Law (1978).

De Geest, G., \&Wuyts F. (1999). Penalty Clauses and Liquidated Damages. https://reference.findlaw.com/lawandeconomics/4610-penalty-clauses-and-liquidateddamages.pdf

Erdem, M. (2009). Determination of Compensation by Agreement. (In Turkish) http://webftp.gazi.edu.tr/hukuk/sorumluluk/s_5.pdf

Eren, F. (1999). General Provisions of the Law of Obligations (5th ed.). Istanbul: Beta. (In Turkish)

García, M. I. (2012). Enforcement of Penalty Clauses in Civil and Common Law: A Puzzle to Be Solved by the Contracting Parties. European Journal of Legal Studies, 5, 95-124.

Gassim Obeidat, M. Y. (2004). The "Penalty" Clause in English Law: A Critical Analysis and Comparison with Jordanian Law. PHD Thesis, Leeds: University of Leeds.

Graves, J. (2012). Penalty Clauses and the CISG. Journal of Law and Commerce, 30, 153-172. https://doi.org/10.5195/JLC.2012.2

International Institute for the Unification of Private Laws (UNIDROIT) (2010). Principles on International Commercial Contracts. Rome.

Kılıçoğlu, M. A. ( 2015). General Provisions of the Law of Obligation (Turkish) (19th ed.). Ankara: Turhal KitabEvi yayınlar.

Mulugeta, M. A. (2010). Ethiopia. In International Encyclopedia of Laws: Contracts. Kluwer Law International.

Nordin, E. (2014). The Penalty Clause Bias. MJ, 21, 162-187. https://doi.org/10.1177/1023263X1402100108

Oğuzman, M. K., \& Turgut, M. Ö. (2009). General Provisions of the Law of Obligations (Turkish) (7th ed.). Istambul: Vedat kitapclik.

Oğuzman, M. K., \& Turgut, M. Ö. (2014). General Provisions of the Law of Obligations (Turkish) (11th ed.). Istanbul: Vedatkitapclik.

Pieck, M. (1996). A Study of the Significant Aspects of German Contract Law. Annual Survey of Int'l. \& Comp. Law, 3, 111-176.

Reisoğlu, S. (2006). General Provisions of the Law of Obligations (16th ed.). Istanbul: Beta.

Restatement (Second) of Contracts (2017). https://www.nylitigationfirm.com/files/restat.pdf

Schwartz, A., \& Edlin, A. (2003). Optimal Penalties in Contracts. Chicago-Kent Law Review, 78, 33-54.

Scottish Law Commission (1999). Report on Penalty Clauses. https://www.scotlawcom.gov.uk/files/1812/7989/6621/rep171.pdf

Şener, E. (1992). Cases and References on Turkish Civil Code and Code of Obligation. Seçkin yayınlar. (In Turkish)

Solorzano, J. S. (2009). An Uncertain Penalty: A Look at the International Community's 
Inability to Harmonize the Law of Liquidated Damage and Penalty Clauses. Law and Business Review of the Americas, 15, 779-818.

Study Group on a European Civil Code \& Research Group on EC Private Law (2009). Draft Common Frame of Reference (DCFR): Principles, Definitions and Model Rules of European Private Law.

http://ec.europa.eu/justice/policies/civil/docs/dcfr_outline_edition_en.pdf

Tamer, A. (2013). Penalty Clauses from the Perspectives of Traders. TAAD, 4, 732-769. (In Turkish)

Tiryaki, M. (2005). Penalty Conditions in Private Law Regime. Istanbu: İstanbul KültürÜniversitesi. (In Turkish)

Turkish Code of Obligation (6098/2011).

Turkish Commercia Code (6102/2011).

UN Uniform Rules on Contract Clauses for an Agreed Sum Due up on Failure of Performance (A/38/17/Annex I A/CN.9/ 243, annex I).

Vitkus, S. (2013). Penalty Clauses within Different Legal Systems. Social Transformations in Contemporary Society.

https://stics.mruni.eu/wp-content/uploads/2013/06/153-162.pdf 